\title{
Hubungan Usia dan Berat Badan Dengan Ukuran Lingkar Penis Anak Menggunakan O-Meter: Sirkumsisi Metode Klem
}

\author{
Dewi Karita ${ }^{1}$, M Fadhol Romdhoni ${ }^{1,2}$ \\ ${ }^{1}$ Fakultas Kedokteran, Universitas Muhammadiyah Purwokerto \\ ${ }^{2}$ Dokter di Rumah Sunatan Purwokerto
}

\begin{abstract}
Abstrak
Latar belakang:

Sirkumsisi atau khitan atau sunat adalah prosedur yang biasa dilakukan dalam operasi. Prosedur ini sama tuanya dengan peradaban manusia, dimulai pada abad pertengahan. Sekitar 25-33\% dari total populasi laki-laki di dunia disunat. Di AS, rata-rata satu juta bayi laki-laki yang baru lahir disunat setiap tahunnya. Tingkat sunat di AS setinggi 70\%, sementara di Inggris itu adalah 6\%. Di Nigeria, tingkat sunat diperkirakan 87\%. Di Indonesia usia yang paling sering adalah 5-12 tahun. Banyak metode sirkumsisi yang digunakan saat ini, salah satunya dengan metode klem.
\end{abstract}

\section{Metode:}

Metode dari penelitian ini adalah retrospektif menggunakan rekam medis selama periode 1 desember - 31 desember 2017 dan diperoleh data sebanyak 57 sampel. Sampel merupakan pasien yang telah dilakukan tindakan sirkumsisi menggunakan metode klem merk Mahdian Klem.

\section{Hasil dan Kesimpulan:}

Lingkar penis dipengaruhi oleh usia dengan nilai signifikansi $0,038(\mathrm{p}<0,05)$ dan juga dipengaruhi oleh berat badan dengan nilai signifikasi $0,042(\mathrm{p}<0,05)$ sehingga disimpulkan bahwa ukuran lingkar penis dipengaruhi oleh usia dan berat badan yaitu semakin bertambah usia maka ukuran lingkar penis semakin besar, begitu pula dengan berat badan, semakin bertambah berat badan maka ukuran lingkar penis semakin besar.

\section{Diskusi:}

Ukuran lingkar penis semakin bertambah seiring dengan pertambahan usia dan berat badan. Tingkat keberhasilan sunat menggunakan metode klem (plastibell) tanpa komplikasi tercatat sebanyak 196 kasus (80,00\%) sedangkan 49 kasus $(20,00 \%)$ mengalami komplikasi. Waktu penyembuhan luka rata-rata 25,5 \pm 4,6 hari serta tidak menemukan adanya deformitas penis atau komplikasi jangka panjang lainnya. Sunat tidak mempengaruhi dorongan seksual atau ejakulasi berdasarkan skor persediaan fungsi seksual pria singkat.

Kata Kunci : Sirkumsisi, Khitan, Klem, Lingkar penis 


\title{
Relationship Between Age and Weight With Penile Circumference Using O-Meter: Circumcision Clamp Technique
}

\author{
Dewi Karita ${ }^{1}$, M Fadhol Romdhoni ${ }^{1,2}$ \\ ${ }^{1}$ Faculty of Medicine, University Muhammadiyah of Purwokerto \\ ${ }^{2}$ Doctor in Rumah Sunatan, Purwokerto
}

\begin{abstract}
Background:

Circumcision is one of most common in operating procedure. This procedure was as ages as human civilization, started at middle ages. Around 25-33\% from total men population in the world are circumcised. In US, around one million newborn baby boy are circumcised every year. Circumcised level in US is about 70\%, while in UK is $6 \%$. In Nigeria, circumcised level is around 87\%. In Indonesia most common age for circumcision is 5-12 years old. There are many circumcision method these days, one of them is by clamp method.
\end{abstract}

\section{Method:}

This was a retrospective study using medical records from 1 December - 31 December 2017 and able to conduct 57 samples. Sample were patients whose had been circumcised with clamp method by Mahdian clamp.

\section{Result:}

The size of penis circumference is related to age $(\mathrm{p}=0.038)$ and also related to body weight $(\mathrm{p}=0.042)$, so the conclusion is that size of penis circumference is related to age and also body weight, which are the older the age size of penis circumference is bigger, as well as body weight, the more the body weight size of penis circumference is bigger.

\section{Discussion:}

Size of penis circumference is increasing along age and body weight. The level of success of circumcision by clamp method (plastibell) without complication have 196 cases (80\%) and 49 cases (20\%) have complications. Time of wound recovery approximately $25.5 \pm 4.6$ days and found no penis deformity or other long-term complication. Circumcision does not affect sexual drive and ejaculation based on supply man sexual function score.

Keyword: Circumcision, Clamp technique, Penile circumference

\section{Pendahuluan}

Sirkumsisi atau khitan atau sunat adalah prosedur yang biasa dilakukan dalam operasi. Prosedur ini sama tuanya dengan peradaban manusia, dimulai pada abad pertengahan. Prosedurnya terus berkembang sampai sekarang. ${ }^{1}$ Sirkumsisi atau khitan atau sunat adalah ritual kuno yang dilakukan di berbagai komunitas termasuk orang Mesir kuno, aborigin Australia, dan Afrika. Alasan agama, budaya, medis, dan kesehatan diketahui sebagai indikasi utama prosedur ini. Biasanya, hal itu dilakukan pada masa neonatal namun bisa dilakukan pada usia berapapun. ${ }^{2,3,4}$ Saat ini, meskipun sunat laki-laki adalah salah satu prosedur pembedahan yang paling umum dilakukan di seluruh dunia dengan perkiraan bahwa pada orang-orang muda yang disunat secara bersamaan, ini terus menjadi prosedur yang diperdebatkan, dengan pendukung dan penentang praktik yang sama kuatnya. Selama bertahun-tahun, rekomendasi telah berubah untuk mencerminkan bukti ilmiah yang ada. Dalam laporan paling baru diterbitkan oleh American Academy of the Children menyimpulkan bahwa sirkumsisi bermanfaat bagi kesehatan dari bayi 
baru lahir. Manfaat spesifik termasuk mengurangi risiko mendapatkan infeksi saluran kemih, Human Immunoductency Virus (HIV) dan beberapa infeksi menular seksual lainnya, dan kanker penis. Secara khusus, bukti yang menghubungkan sunat laki-laki dengan penurunan penularan HIV telah menyebabkan masyarakat global merekomendasikan program penanganan massal sebagai strategi pencegahan HIV .,6

Sekitar 25-33\% dari total populasi laki-laki di dunia disunat. Di AS, rata-rata satu juta bayi laki-laki yang baru lahir disunat setiap tahunnya. Tingkat sunat di AS setinggi $70 \%$, sementara di Inggris itu adalah 6\%. Di Nigeria, tingkat sunat diperkirakan $87 \% .^{2}$ Secara medis tidak ada batasan umur untuk melakukan sirkumsisi. Di Indonesia usia yang paling sering adalah 5-12 tahun dan banyaknya anak laki-laki untuk melakukan sirkumsisi adalah $85 \%$ (8,7 juta). Angka kejadian sirkumsisi pada pria dipengaruhi oleh pola geografis yang berbeda. Di Asia Tenggara dan pulau Pasifik memiliki prevalensi $27 \%$ tersebar di Indonesia, Pakistan, Bangladesh, dan Filipina. Tiga belas negara berkembang seperti di Afrika Utara dan Timur Tengah memiliki prevalensi sebesar 14\% dan 28 negara Afrika Sub-Sahara memiliki prevalensi sebesar $45 \% .^{7,8}$

Banyak metode sirkumsisi yang digunakan saat ini, mulai dari metode konvensional dengan pisau bedah (bisturi) dengan atau tanpa penjahitan, Electrosurgery dengan alat diathermi dan Electrocautery, dengan metode klem, preputium ditarik keluar distal kemudian tabung dari klem dimasukkan sedemikian rupa sehingga bagian proksimal dari tabung dari klem berada pada korona glandis. Pisau bedah digunakan untuk menghilangkan preputium berlebihan. Gland penis sudah terlindungi dengan aman oleh tabung dari klem sehingga tidak akan cedera oleh pisau bedah yang digunakan. Tidak ada jahitan pada metode ini. ${ }^{2}$

\section{Metode}

Penelitian ini dilakukan di Rumah Sunatan Purwokerto, Banyumas, Jawa Tengah dengan metode retrospektif menggunakan rekam medis selama periode 1 desember - 31 desember 2017 dan diperoleh data sebanyak 57 sampel. Sampel merupakan pasien yang telah dilakukan tindakan sirkumsisi menggunakan metode klem merk Mahdian Klem. Alat untuk mengukur lingkar penis menggunakan O-meter.

Adapun tujuan penelitian ini adalah untuk mengetahui ukuran lingkar penis pada anak-anak di wilayah Indonesia sehingga hasil dari penelitian ini dapat digunakan untuk strategi penyediaan klem supaya ukurannya sesuai dengan yang dibutuhkan pasien.

\section{Hasil dan Kesimpulan}

Pada penelitian ini diperoleh data sebanyak 57 sampel. Seluruh sampel menampilkan data tentang usia, berat badan, dan lingkar penis menggunakan O-meter. Data lebih lengkap dapat dilihat pada tabel 1 berikut ini:

Tabel 1. Distribusi usia, berat badan, dan lingkar penis

\begin{tabular}{|c|c|c|}
\hline $\begin{array}{c}\text { Kelompok } \\
\text { Usia } \\
\text { (dalam } \\
\text { Tahun) }\end{array}$ & $\begin{array}{c}\text { Rata - Rata } \\
\text { Berat Badan } \\
\text { (Kg) }\end{array}$ & $\begin{array}{c}\text { Rata - Rata } \\
\text { Lingkar Penis } \\
\text { (O-Meter) }\end{array}$ \\
\hline $0-2$ & 3,8 & 12 \\
\hline $3-5$ & 22 & 16 \\
\hline $6-8$ & 27,8 & 15,6 \\
\hline $9-11$ & 31,5 & 16,6 \\
\hline
\end{tabular}




\begin{tabular}{|l|l|l|}
\hline $12-14$ & 39,6 & 22,8 \\
\hline
\end{tabular}

Grafik 1. Perbandingan antara lingkar penis dengan usia dan berat badan

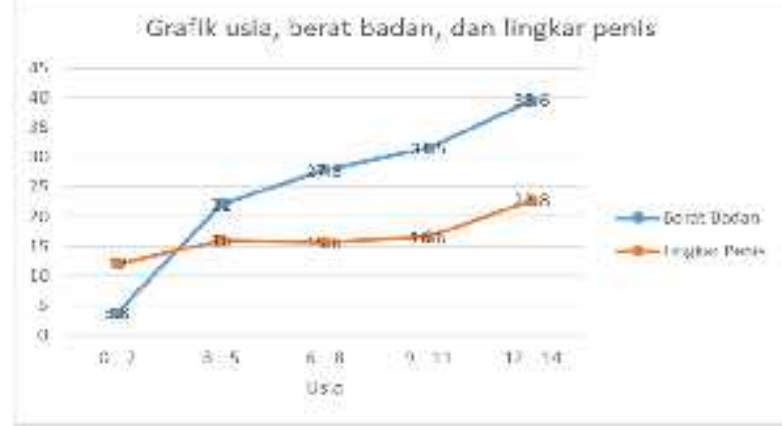

Pada grafik 1 di atas tampak bahwa semakin bertambahnya usia maka ukuran lingkar penis juga bertambah, demikian juga dengan pertambahan berat badan maka ukuran lingkar penis juga bertambah pula.

Dari data tersebut, dilanjutkan uji statistic untuk mengetahui kekuatan hubungan antara lingkar penis dengan usia dan berat badan. Adapun uji statistic yang dilakukan adalah uji korelasi dengan hasil sebagai berikut:

Tabel 2. Hasil uji korelasi

\begin{tabular}{|c|c|c|c|c|}
\hline \multicolumn{5}{|c|}{ Correlations } \\
\hline & & Usia & $\begin{array}{c}\text { Berat } \\
\text { Badan }\end{array}$ & $\begin{array}{l}\text { Lingkar } \\
\text { Penis }\end{array}$ \\
\hline \multirow[t]{3}{*}{ Usia } & $\begin{array}{l}\text { Pearson } \\
\text { Correlation }\end{array}$ & 1 & $.955^{*}$ & $.899^{*}$ \\
\hline & $\begin{array}{l}\text { Sig. (2- } \\
\text { tailed) }\end{array}$ & & .012 & .038 \\
\hline & $\mathrm{N}$ & 5 & 5 & 5 \\
\hline \multirow[t]{3}{*}{$\begin{array}{l}\text { Berat } \\
\text { Badan }\end{array}$} & $\begin{array}{l}\text { Pearson } \\
\text { Correlation }\end{array}$ & $.955^{*}$ & 1 & $.892^{*}$ \\
\hline & $\begin{array}{l}\text { Sig. (2- } \\
\text { tailed) }\end{array}$ & .012 & & .042 \\
\hline & $\mathrm{N}$ & 5 & 5 & 5 \\
\hline \multirow[t]{3}{*}{$\begin{array}{l}\text { Lingkar } \\
\text { Penis }\end{array}$} & $\begin{array}{l}\text { Pearson } \\
\text { Correlation }\end{array}$ & $.899^{*}$ & $.892^{*}$ & 1 \\
\hline & $\begin{array}{l}\text { Sig. (2- } \\
\text { tailed) }\end{array}$ & .038 & .042 & \\
\hline & $\mathrm{N}$ & 5 & 5 & 5 \\
\hline
\end{tabular}

*. Correlation is significant at the 0.05 level (2-tailed).
Dari tabel 2 diketahui bahwa lingkar penis dipengaruhi oleh usia dengan nilai signifikansi 0,038 $(\mathrm{p}<0,05)$ dan juga dipengaruhi oleh berat badan dengan nilai signifikasi $0,042 \quad(\mathrm{p}<0,05) \quad$ sehingga dapat disimpulkan bahwa ukuran lingkar penis dipengaruhi oleh usia dan berat badan yaitu semakin bertambah usia maka ukuran lingkar penis semakin besar, begitu pula dengan berat badan, semakin bertambah berat badan maka ukuran lingkar penis semakin besar.

Pada penelitian ini yang diukur adalah lingkar penis, bukan panjang dari penis, sehingga kesan adanya pertentangan dengan penelitian lain yang menyatakan bahwa ukuran penis tampak pendek pada orang yang gemuk tidak akan terjadi.

\section{Diskusi}

Pada penelitian ini dapat diketahui bahwa ukuran lingkar penis semakin bertambah seiring dengan pertambahan usia dan berat badan. Hal tersebut sejalan dengan penelitian terdahulu yang menyatakan bahwa testis tidak menunjukkan adanya peningkatan ukuran sampai timbulnya pubertas pada usia 11 tahun, dimana pertumbuhan penis meningkat secara bertahap setelah kelahiran. Namun, baik perkembangan penis maupun testis menunjukkan pertumbuhan puncak dari usia 12 sampai 16 tahun, yang bertepatan dengan pertumbuhan pubertas laki-laki yang maksimal. Data menunjukkan perkembangan pubertas sebelumnya untuk populasi penelitian ini daripada populasi serupa beberapa dekade yang lalu. ${ }^{9}$ Panjang penis yang membentang meningkat secara signifikan sebesar 0,7 sampai $1,1 \mathrm{~cm}$ pada sebagian besar kelompok usia $(\mathrm{p}<0,05)$. Ukuran 
antropometri saat ini pada anak-anak Korea seperti tinggi badan, berat badan, dan ukuran testis meningkat dibandingkan dengan yang diteliti pada tahun $1987 .{ }^{10}$

Nilai rata-rata untuk panjang penis, lingkar midshaft, dan lingkar koroner adalah 3,34, 3,05, 3,29 cm pada masa bayi, 4,28, 3,86, 4,1 cm selama 4-5 tahun, dan 5,25, 4,78, 5,05 cm selama 9-10 tahun. , masing-masing. Panjang penis meningkat dengan bertambahnya usia pada kelompok usia lanjut, namun tidak memiliki korelasi langsung dengan tinggi, berat badan, atau BMI. Dimensi penis pada anak-anak India Utara ditemukan secara statistik lebih kecil dibandingkan dengan kebanyakan penelitian dari negara lain. ${ }^{11}$

Pada penelitian yang lain, antropometri penis yang di dalamnya termasuk ukuran lingkar penis, selain dipengaruhi oleh usia dan berat badan juga dapat dipengaruhi oleh usia kehamilan. Ada sebanyak 150 anak laki-laki yang baru lahir diteliti, berat lahir rata-rata bayi adalah $3455 \pm 354,2 \mathrm{~g}$ dan rata-rata usia kehamilan saat lahir adalah 39,5 \pm 1,18 minggu. Pada bayi, panjang penis rata-rata adalah $3,19 \pm 0,37 \mathrm{~cm}$ (kisaran $2-4 \mathrm{~cm})$ dan diameter penis rata-rata adalah $1,95 \pm 0,44 \mathrm{~cm}$. Ada korelasi positif yang signifikan antara usia kehamilan saat kelahiran dan panjang penis pada bayi $(\mathrm{r}=0,19, \mathrm{p}$ $=0,042)$, sedangkan tidak ada korelasi yang signifikan antara panjang penis dan berat lahir $(\mathrm{r}=0,10, \mathrm{p}=$ $0,179) .^{12}$

Pada penelitian ini, menggunakan data dari pasien yang disirkumsisi menggunakan metode klem. Dalam sebuah penelitian tentang komplikasi metode klem menyatakan bahwa tingkat komplikasi total adalah
2,15\%. Luka kembali terbuka (dehiscence) (1,07\%), infeksi $(0,54 \%)$, dan perdarahan $(0,54 \%)$ adalah komplikasi yang ditemui. Waktu penyembuhan luka diamati pada rata-rata $25,5 \pm 4,6$ hari serta tidak menemukan adanya deformitas penis atau komplikasi jangka panjang lainnya. ${ }^{13}$ Pada masing-masing kelompok, tingkat komplikasi tidak berbeda antara anak-anak yang memiliki berat badan normal, dibandingkan dengan berat badan di bawah atau di atas (10\%). Ada korelasi positif yang signifikan antara umur dan berat subjek dengan waktu pemisahan cincin $(\mathrm{P}$ $<.001) .{ }^{14}$

Tingkat keberhasilan sunat menggunakan metode klem (plastibell) tanpa komplikasi tercatat sebanyak 196 kasus $(80,00 \%)$ sedangkan 49 kasus $(20,00 \%)$ mengalami komplikasi. Pada neonatus tercatat sebanyak 04,44\% kasus, sedangkan rasio ini adalah 29,03\% pada bayi. Komplikasi yang paling umum adalah penundaan pemisahan cincin pada 17 kasus $(6,93 \%)$, perdarahan pada 12 kasus $(4,89 \%)$, infeksi superfisial lokal pada 12 kasus (4,89\%), dan migrasi cincin proksimal pada 07 kasus $(2,85 \%) .{ }^{15}$ Sunat tidak mempengaruhi dorongan seksual atau ejakulasi berdasarkan skor persediaan fungsi seksual pria singkat. Fungsi ereksi dan kepuasan keseluruhan membaik setelah disunat. ${ }^{13}$

\section{Konflik kepentingan (Conflict of interest)}

Menurut panduan dari International Committee of Medical Journal Editors (ICMJE), penelitian ini tidak memiliki unsur konflik kepentingan.

\section{Ucapan terima kasih}

Terima kasih kami haturkan kepada jajaran Rumah Sunatan Purwokerto yang telah berkenan membantu kami dalam melaksanakan penelitian. 


\section{Referensi}

1. Lukong C. Circumcision Controversies and Prospects. J Surg Tech Case R. 2011;3(2):656.

2. Abdulwahab-Ahmed A, Mungadi I. Techniques of male circumcision. J Surg Tech Case Rep [Internet]. 2013;5(1):1. Available from: http://www.jstcr.org/text.asp?2013/5/1/1/11858 8

3. Jimoh BM, Odunayo IS, Chinwe I, Akinfolarin OO, Oluwafemi A, Olusanmi EJ. Plastibell circumcision of 2,276 male infants: A multicentre study. Pan Afr Med J. 2016;23:1-8.

4. Mulia YA, Anda P, Adiputra T, Denpasar PS. Teknik Guillotine Dan Gomco Clamp Pada Sirkumsisi Guillotine and Gomco Clamp Technique on Circumcision. :1-18.

5. Anwer AW, Samad L, Iftikhar S, Baig-Ansari N. Reported Male Circumcision Practices in a Muslim-Majority Setting. Biomed Res Int. 2017;2017.

6. World Health Organization/Joint United Nations Programme on HIV/AIDS. New Data on Male Circumcision and HIV Prevention : Policy and Programme Implications. WHO/UNAIDS Tech Consult Male Circumcision HIV Prev Res Implic Policy Program Montreux Conclusions Recomm. 2007;(March):1-10.

7. Drain PK, Halperin DT, Hughes JP, Klausner JD, Bailey RC. Male circumcision, religion , and infectious diseases : an ecologic analysis of 118 developing countries. 2006;10:1-10.

8. World Health Organization. Neonatal and child male circumcision: a global review. Unaids [Internet]. 2010;1-108. Available from: http://www.who.int/hiv/pub/malecircumcision/ neonatal_child_MC_UNAIDS.pdf

9. Tomova A, Deepinder F, Robeva R, Lalabonova H, Kumanov P, Agarwal A. Growth and Development of Male External Genitalia A Cross-sectional Study of 6200 Males Aged 0 to 19 Years. Arch Pediatr Adolesc Med [Internet]. 2010;164(12):1152-7. Available from: http://ccf.org/reproductiveresearchcenter/docs/ agradoc391.pdf

10. Lee JH, Ji YH, Lee SK, Hwang HH, Ryu DS, Kim KS, et al. Change in penile length in children: Preliminary study. Korean J Urol. 2012;53(12):870-4.

11. Bhat A, Upadhyay R, Bhat M, Sabharwal K, Singla M, Kumar V. Penile anthropometry in North Indian children. Indian J Urol [Internet].
2015;31(2):106-10. Available from: http://www.ncbi.nlm.nih.gov/pmc/articles/PM C4397544/

12. Akin Y, Ercan O, Telatar B, Tarhan F. Penile size in term newborn infants. Turk J Pediatr. 2011;53(3):301-7.

13. Senel FM, Demirelli M, Misirlioglu F, Sezgin T. Adult Male Circumcision Performed with Plastic Clamp Technique in Turkey. Urol J [Internet]. 2012;9(4):700-5. Available from: http://search.ebscohost.com/login.aspx?direct=t rue $\& \mathrm{db}=\mathrm{a} 9 \mathrm{~h} \& \mathrm{AN}=84952279 \&$ site $=$ ehost-live

14. Mousavi SA, Salehifar E. Circumcision complications associated with the Plastibell device and conventional dissection surgery: a trial of 586 infants of ages up to 12 months. Adv Urol. 2008;2008(January):606123.

15. Moosa FA, Khan FW, Rao MH. Comparison of complications of circumcision by "plastibell device technique" in male neonates and infants. J Pak Med Assoc. 2010;60(8):664-7. 
